\title{
The Transformation of a Young Continent: Dimensions of Africa Rising
}

Waniiru M Gitau'

Abstract: In the past, there has been agreement across board concerning Africa's malaise. Therefore, winds of change that have been occurring over the last two decades are noticeable, and a new narrative has been replacing the earlier jaded perspective. A light is being focused on the new generation of Africans driving technology, culture, education, and entrepreneurship among other areas, shifting the continent from earlier marginalized perspectives, to a new world which other regions are courting for business opportunity. What is the nature of the transformation that has given a boost to the continent? Broadly, this newly reinvigorated perspective is referred to as Africa rising. It is a conversation that is still taking shape. This paper contributes to the discourse by outlining the changes that have occurred. It begins by exploring the continent's jaded historical background, explores change in the political space since the 1990s, which in turn created an environment that intersected with the revolution in information technology to enable an economic turnaround. Lastly, the paper explores the ongoing demographic transition, with a particular emphasis on the continent's young population as the vital driving force into the future of the continent.

Keywords: Africa, social change, youth, technology.

A transformação de um jovem continente: dimensões da África em ascensão 
Resumo: No passado, houve um consenso além-fronteiras sobre o mal-estar da África. Portanto, os ventos de mudança que vêm ocorrendo nas duas últimas décadas são perceptíveis, e uma nova narrativa vem substituindo a perspectiva anterior. Uma luz é colocada na nova geração de africanos impulsionando a tecnologia, cultura, educação e empreendedorismo, entre outras áreas, deslocando o continente de perspectivas marginalizadas anteriores, para um novo mundo em que outras regiões estão buscando oportunidades de negócios. Qual é a natureza da transformação que impulsionou o continente? Em linhas gerais, essa nova perspectiva revigorada é chamada de ascensão da África. É uma conversa que ainda está tomando forma. Este artigo contribui para esse discurso na medida em que delineia as mudanças ocorridas. $\mathrm{O}$ texto começa por explorar o passado histórico cansado do continente; a mudança no espaço político desde os anos 1990, que por sua vez criou um ambiente que se cruzou com a revolução na tecnologia da informação para permitir uma reviravolta econômica. Por último, o documento explora a transição demográfica em curso, com uma ênfase particular na população jovem do continente como a força motriz vital para o futuro do continente.

Palavras-chave: África, mudança social, juventude, tecnologia.

\section{Introduction}

For years, Africa has been synonymous with a variety of challenges. Scholars have highlighted a range of explanations on what is wrong. Paul Gifford writes that in 1960's Africa was seen to be held back, and modernization through democratic and bureaucratic state arrangements was recommended. In 1970s, it was claimed that modernization was not working as nations were being mismanaged by the political post-colonial elite. In 1980s, emphasis on the state as an agent of development was discredited, western financial institutions enforced structural adjustment programs, and markets were tasked to lead the development agenda. In 1990s, the World Bank championed good governance comprising accountability, transparency, and rule of law, facilitated by inclusive multiparty politics. (Gifford, 1998: 10-12) Elias Bongmba ascribes culpability to African leaders in four key phrases: privatization of power, pauperization and prodigalization of the state, and proliferation of violence.(See Bongmba, 2006: 9-39) Emmanuel Katongole uses poignant narratives to show that the dysfunction simply reflects the dark side that is deeply ingrained in the western nations that created the nation-state in Africa. In other words, Africa's dysfunction is not the exception - it is the logical outcome of the activities of the colonial 
powers.(Katongole, 2011: 1-49) More recently, an incisive, macro-analytical scrutiny done by African born World Bank economist, Dambisa Moyo, faults the misconstrued aid industry for the crises of post-independent Africa. For 50 years, over US $\$ 1$ trillion dollars have been transferred to Africa under the sacrosanct idea that bilateral government aid would fast track economic growth. Yet this has left African people worse off because aid gives African leaders little incentive to develop the economies, yet it burdens future generations with massive debt.(Moyo; Ferguson 2010, xvii-xix; Collier, 2007: 99-123)

So, there is agreement across board concerning Africa's malaise. However, over the last two decades, a new narrative has been emerging. Aubrey Hruby and Jake Bright, senior advisors to Fortune 500 companies, write that in place of the old continent, a cadre of remarkably talented Africans working on technology, fashion, music, film, education, entrepreneurship, and investment is thrusting the continent from the world's margins onto the global mainstream. The freshly reinvigorated class of Africans is intersecting with new technological and global developments to take charge of business, political and development agendas, altogether setting economies on an upward swing and reshaping the fortunes of the continent.(Bright; Hruby, 2015: 9) Broadly, this newly reinvigorated perspective that has been buzzing for a while is referred to as Africa Rising. It is a conversation that is still taking shape. This paper contributes to the discourse by outlining the changes that have occurred, and how the continent's young population is taking center-stage in the transformation.

Four dimensions are important to understanding Africa's transformation. First, a retrospective historical preview shows the complex conditions that African has to work through. Once context is understood, three key changes are highlighted. One, the increasingly democratic political space enables other kinds of social changes. Second, recent economic developments are progressively aligned to the global economy. Third, there are clear social indicators of progress, starting with the lowering of child mortality rates, the growth of a youth bulge, higher rates of secondary and tertiary education. These are a work in progress, but viewed altogether, they suggest that Africa is not exactly as marginalized as imagined by non-Africans.

\section{Africa's jaded historical background}

There are deep structural and historical reasons for Africa's diminished place in the global economy throughout the $20^{\text {th }}$ century. First, when the rest of the world was looped into the global trade map through improved maritime travel and the industrial revolution, the abhorrent slave trade placed Africa at the 
losing end of international trade. An estimated 12 million Africans were shipped through "doors of no return" to the Americas from the west coast, and to the Arabian world from the east coast.(Hanciles, 2009) Soon after slave trade was abolished, western nations carved up the continent at the Berlin Conference of 1884 to 1885 . Martin Meredith cynically observes how with little knowledge of the vastness of the continent, European politicians bargained over spheres of interest they intended to establish over the African landmass.(Meredith, 2006: 1-5) By the time the scramble was over, some 10,000 African polities had been amalgamated into forty colonies and protectorates. On the ground European rule was enforced by treaty and conquest. African communities put up spirited struggles against the invaders, but under conditions that tell a sad tale, rebellion was quickly quelled. After expending so much effort in acquiring the empires, colonial powers lost interest because very few parts of Africa offered prospects for immediate wealth. Administration was kept to a minimum, and until later in the colonial timeline, education was left to missionaries. Economic activity was ceded to commercial companies whose goal was exploitative extraction. Railroads were constructed, not to facilitate intra-African trade, but to carry all kinds of African goods to ports and on to Europe, rather than connect the vast continent. The few functions of government, little more than instruments of domination, were limited to maintaining law and order, raising taxation and providing infrastructure of roads and railways.(Mazrui, 1980: 23-45)

The colonial period properly lasted from 1885 to about 1960 . Although a relatively short time in world-historical terms, this seventy-five-year period profoundly restructured the continent along three parameters: political, economic, and sociocultural arrangements. Prior to colonization, African societies lived in territorial units that varied greatly in organization and scale, depended on the localized subsistence farming, pastoral keeping and limited intertribal trade. European colonies took no account of existing monarchies, chiefdoms, or territorial spread of tribes. Colonial boundaries cut through culture groups and enclosed hundreds of independent groups with no common history or language. ${ }^{2}$ (Meredith, 2006: 2) Thrown together this way, Africans had to learn to

2 For instance, in Kenya, forty-two distinct people groups were combined to create the nation. The Bakongo of central Africa were partitioned between the French Congo, Belgian Congo and Portuguese Angola. Somaliland in north-east was carved up between Britain, Italy and France, and upon independence, Somali people found themselves scattered in Kenya, Ethiopia and Somali, a factor that has come to haunt all these countries through terrorist groups. Nigeria contained some 250 ethno-linguistic groups. Kingdoms that had historically been enemies such as the Buganda and Bagamoyo in Uganda were linked in the same colony. 
expand their ethnic identities and peasant subsistence into national consciousness. Exigencies of the colonial situation were such Africans did not immediately apprehend the gravity of the new social arrangements. Yet ever since independence, one of Africa's enduring problems has been the difficulty of forging loyalty to state over tribe, which explains political opportunism, uneven economic development and neopatrimonialism. (Gifford, 1998: 5-7; Maathai, 2009).

Economically, colonial occupation changed Africa from basic subsistence facilitated by kinship and communal networks, to organization of life around wage-based labor. Unfortunately, the extractive economy worked for those closest to power and means of production. With a materialist worldview drawn from Europe's rational-scientific perspective, the state was expected to offer social integration through state bureaucracy, socialization through education, and a hurried development agenda. In the immediate post-colonial decade, Africa was highly optimistic about economic progress; the first few decades were a period of intense experimentation to fast-track development.(Hamrell; Nordberg, 1987) However, the attempt to cope with all the exogenous political, economic and social changes introduced continent-wide structural dissonances that limited the continent's inability to streamline political power, to develop its rich resources and secure the social lives of its people. The structural dissonances were compounded by what economists refer to as unfavorable initial conditions, that is, prior natural circumstances that affect policy choices. ${ }^{4}($ Temple, 1998; Collier, 2007: 17-64)intractable disease and volatile climate. Ethnic diversity is another. It affects political stability and undermines investment. The other end of the spectrum are results of prior policies: education, health care. In the middle are variables influenced by policy, but can change slowly: social arrangements, income distribution (inequity The quest for quick progress also accrued costly legacies. African nations embraced foreign aid without the proper economic and

3 Patrimonialism is defined as the kind of authority that has a father has on his children, the lower officials being retainers whose position depends on a leader to whom they owe allegiance. Patrimonialism is held together by loyalty or kinship ties rather than hierarchy of administrative grades. In legal structures, the apparatus of modern nation states looks legitimate, but the officials still exercise their powers as a form of private property. The result of such a state is corruption and clientelism where public office is considered the route to personal wealth and power and support is ensured by a system of exchange in which the superior provides security for an inferior in exchange for political support. This system does little to develop the efficiency, accountability and legitimacy necessary in the modern state.

4 "Initial conditions" are best be seen along a spectrum. At one end are exogenous factors such as geography, intractable disease, volatile climate and ethnic diversity. The other end of the spectrum are results of previous policies: education, health care. In the middle are variables influenced by policy, but can change slowly: social arrangements, income distribution (inequity). Collier names them as traps of conflict, poor natural resources, landlock and bad neighbors and bad governance. 
bureaucratic structures to absorb it. Leaders also lost perspective on capacities and limitations of aid. Later interventionist efforts of donor communities such as structural adjustment programs were poorly designed and inadequately executed. Further, promising intellectuals were considered threats to the hegemony of inept political rulers and their constructive critique was curtailed. All these issues accumulated into the precarious state that has seen Africa marginalized as much of the rest of the world has progressed.

Yet as noted in the beginning, the narrative has been changing. We may observe three key developments behind the turn-around: expansion of democratic space, economic realignment to the global economy, facilitated by the revolution in information technology, and a demographic change with a large youth population, in which education is a key factor in their role in the turn around. We will look at each of these in turn.

\section{Political expansion in democratic space}

In the late 1980s and early 1990s, a slow and often brutal series of transitions out of one-party, military regimes or the rule of "big men" (Russell, 1999)', begun to occur throughout the continent. By June 2003, 44 out of 48 Sub-Saharan Africa's states had conducted a first round of elections, 33 had gone through a second election cycle, 20 had completed three uninterrupted cycles, 7 had held four more consecutive elections. Majority of these countries had become more democratic with each election cycle.(Lindberg, 2006) Lindberg concludes that elections have notably advanced Africa's democracy, in at least six areas. One, elections foreground fundamentals of equal citizenship, namely the right to universal suffrage, freedom of association, public debate, choice and the right to form and join civic organizations. Second, once people discover their agency in forming democratic institutions, participation and competition, they learn the values inherent in democratic electoral practices, and vocalize their concerns in other social spheres such as schools and work places, with widening ripple effects of change. Third, the competitive element leads to changes in power distribution within the ruling party, reducing the likelihood of impunity against citizens. Fourth, civic organizations for voter education build social capital and organizational experience. Fifth, state institutions such as courts, police, and

5 Presidents Mobutu Sese Seko, General Sani Abacha, Jonas Savimbi, Hastings Banda, Kenneth Kaunda, Jomo Kenyatta, Daniel Moi, Robert Mugambe, Omar El Bashir, Yoweri Museveni are among those had either ruled with an iron hand, tribalized and exploited their countries for power and personal wealth, and, or ruled for unseasonably long terms in the post independent decades. 
the military acquire new roles correlated with defense of civil liberties rather than the kind of control exercised by authoritarian governments. Media entrepreneurs and watchdog organizations also gain space to advance civil liberties. Considering the prior eras, this expanded democratic transformation is remarkable. The continent has experienced fewer coup de tats, and overall, a young crop of leaders has emerged to reflect the young demographics of the continent.

While every incremental step is significant, expansion in democratic processes did not mean an all-out end of social volatility. South Sudan, Central African Republic, and the DRC have experienced politically driven conflict in recent years. Kenya have had to forge a hybrid government following violently contested elections in 2008. Uganda and Zimbabwe's long-time presidents held onto power far longer than expected. Somalia though somewhat stabilized by African Union peace-keeping forces remains an unstable breeding ground for the terrorist group al-Shabaab that attacks on high profile targets in neighboring Kenya. Along with reactive ethnic voting in most nations, corrupt leaders and bureaucratic incompetence are lingering problems. Yet despite persistent contradictions, it is not to be underestimated that in the 2000s, Africans enjoy greater political freedoms than they did in the 1980 os and 1990s. Democracy, even in the more developed countries is never a fait accompli; the institutional and structural scaffolding is always a work in progress, so there remains more work to be done in African democracies.

\section{The economic realignment to the global economy}

Alongside political stabilization, the correlated factor to Africa's changed image has been a markedly improved economic status of many countries. While the political climates begun to shift in the 1990s, the global image of African economies began to change in 2010. Two widely circulated newspaper reports, one by The Economist titled: Africa's Impressive Growth: Africa is one of the World's Fastest Growing Regions showed that Africa had been having 6 out of 10 fastest growing economies in the world over the decade, from 2000 to 2010. (The Economist 2011. Compare this with their article a decade earlier which dubbed the continent as hopeless. ) Further, the article forecast that the continent would produce 7 out of 10 top economies leading up to 2015. The report by The Economist reflected a longer one known as The McKinsey Report, published in 2010.(Roxburgh, et al. 2010)resources, agriculture, and infrastructure together could generate as much as $\$ 2.6$ trillion in revenue annually by 2020 , or $\$ 1$ trillion more than today.,'"URL":"https://www.mckinsey.com/featured-insights/middle-east-and-africa/lions-on-the-move'"'shortTitle":"Lions on the mo 
ve','language”:"en'”'author”:[\{“family":”Roxburgh"',given”:"Charles”\},\{“family”: "Dörr"',given":"Norbert"\},\{“family":"Leke,"'given":"Acha”\},\{“family":”Tazi-Riff i'”'given":"Amine”\},\{“family":”Wamelen"',given":"Arend'”'dropping-particle":"v an"\},\{“family":"Lund'”'given":"Susan"\},\{“family":"Chironga','given":"Mutsa” $\},\{$ “family":"Alatovik,"'given":”Tarik"\},\{“family":"Atkins,'”given":"Charles”\},\{“fam

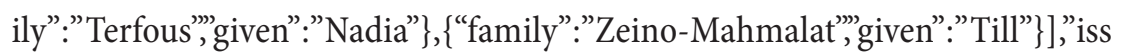
ued":\{“date-parts”:[[“2010”]]\}\}\}],"schema”:"https://github.com/citation-style-language/schema/raw/master/csl-citation.json"\} Numerous other reports by global consulting firms quickly cast the continent as a new investment destination for new profit opportunities.(Bright; Hruby, 2015: 22-23)

Why did the world suddenly notice this growth? Africa's economic recovery begun in the mid-1990s and maintained an upward growth curve through the 2010s.(International Monetary Fund, 2009) One key trigger was the shift in political cross-winds, as detailed above. Yet while the economies had been growing since the 1990s, computation of large amounts of economic activity across the continent was not captured by formal grids of bilateral trade organizations, because it was "the wrong kind of data".(Bright; Hruby, 2015: 30) Its economic outlook was undervalued by a world accustomed to deep-seated afro-pessimism, based on Africa's presumed "horsemen of Africa's apocalypse"(Moyo; Ferguson, 2010: 151): war, poverty, corruption and disease. (Keim, 2013: 3-13) Related to negative stereotypes is what Morten Jerven calls poor numbers, whereby the central measure of accounting for the national income (GDP) has been skewered by the fact that the share of the unrecorded economy is so large, its inclusion in GDP is constrained by unavailability of data. ${ }^{6}(J e r v e n, 2013$, xi-xii: 4-11) Politicians and international monetary organizations working with Africa used official measures that primarily reflected shaky political outlooks, therefore the status given to markets varied with fluctuating contingencies of the state and politics. ${ }^{7}(J e r v e n, 2013: 33)$ Related

6 Jerven's "ethnography of national income accounting in Africa" is a study of the production and use of African economic development statistics. He argues that poor numbers-that is, manipulated, deliberately misleading or simply badly computed numbers - have fundamentally shaped what is known about development in sub-Saharan Africa, which in turn shapes how a wide range of decisions having to do with economic growth are made. That picture has been inaccurate for a long time, he argues, and quantitative basis for knowledge about African economic development remained very fragile. Among the development community, it was always known that the data available on Africa were inaccurate, but the degree of inaccuracy cannot easily be judged-itself a sign of underdevelopment of the region. Yet such numbers provide evidence for major decision makers.

7 Other data deficiencies that hamper a proper understanding include old, inconsistent, unharmonized, un-disaggregated, delayed, un-disseminated, unevaluated, and unanalyzed data. 
to poor numbers is the tendency of statisticians to report about all kinds of African realities, whether talking about education, incidence of disease, poverty and so on, in a language that primarily highlights the negativities and absences rather than in terms that recognize remarkable achievements. Such phrases as "over one-fifth children are out of school" highlights the absence of one child from school rather than highlighting the 4 out of 5 children who are in school, in a continent that has made remarkable strides to get those 4 children to school.

Following the Economist and Mckinsey Report, economists began to revalue some of these problems with African data. Once growth was prorated from the mid-199os, Africa's economy was seen to have grown comparatively faster than many other parts of the developing world. It has had six of the world's fastest-growing economies in the decade of the 2010s. It has been branded as the frontier market by World Street and World Bank, as a new investment destination and as a key player in emerging technologies. To show just how remarkable that growth is, the annual average growth rate of real output increased from 1.8\% between 1980-1989, then 2.6\% between 1990-1999, and 5.33\% in 2000-2009. From 2010 it has remained in the range of 4.5 to $5.5 \%$ per year.(Newman et al, 2016: 3)

The extended growth spurt was driven by a wide range of factors, including better macroeconomic policies, lower public debt, increased political freedom, less conflict, a highly favorable global environment of extended concessional financing, and higher commodity prices for a wide variety of African goods. Inflation in most African countries reverted to single digits, and foreign exchange rates strengthened.(International Monetary Fund, 2009) As of 2008, African countries that sustained growth avoided major policy failures, stabilized their rates of inflation and achieved debt sustainability, sound economic policies, and reinforced their institutions. Even when IMF began to observe a pattern of slowdown from 2010, the slowdown did not return to the previous era of stalled growth and hardship. In the face of the global meltdown, the regional avoided the major macroeconomic instabilities and remained relatively robust.(International Monetary Fund, 2009)

Since the 2010s, there has been an active push to formalize Africa's robust informal sectors as part of the GDP, and to enable the sector to attract investment towards growth. Informal economic activity in Africa at its basic consists transactions that are not recorded by official government agencies. It has therefore not been officially taxed by government, although the small vendors typically pay "informal taxes" to local officials or cartels. Because this sector lacks 
legally enforceable contracts, it is also overlooked by the growth enabling factors such as availability of financing.

Other factors behind Africa's improved GDP in the decade of 2010 are coterminous with other changes. Until recently, a telltale sign of Africa's disconnect from the global markets was the comparative lack of capital investment across global companies. Increasing political stability created an attractive environment for Foreign Direct Investment (FDI). ${ }^{8}$ (Bright; Hruby, 2015: 47) Since 2000 , FDI to Africa increased from US $\$ 12$ billion in 2004 to US $\$ 38$ billion in 2008 , on to US $\$ 55$ billion in 2014. Much of this growing share of capital being invested in Africa is a quest for returns in the wake of stagnating growth in developed markets since the 2008 financial crisis.(Bright; Hruby 2015, Moyo; Ferguson, 2010: 99-102) Related to FDI but distinct from it is the foreign portfolio investment. This is investment into the stocks and bonds of a country. Since 2013, African countries have issued US\$11.9 billion dollars as sovereign Eurobonds. African governments are using the bonds to deliver infrastructure to march their economic growth and meet the structural needs such as electricity, seaports, airports and roads for their emerging middle classes.(Bright; Hruby, 2015: 50-51) Following growing critique of dependence on aid, governments are also using the sovereign bonds to wean themselves off foreign aid. A third form of investment in Africa is coming from diaspora remittances, that is, money sent from Africans abroad to relatives or friends in their home countries. Africa has a significant diaspora population living in America and Europe. African immigrants in America are said to be the most highly educated demographic among immigrants.(Simmons, 2018) As at 2015, Africans sent remittances to Africa amounting to US $\$ 34.8$ billion, which exceeded the amount given in bilateral aid.(World Bank.)

A very important part of the economic turnaround across Africa, and which generates significant amount of growth is the growth of cities, and with cities also comes consumer retail, local transportation, local and international telecommunications, tour and entertainment industries, and a boom in the middleclass housing construction. Newly reinvigorated cities are increasing featuring gleaming skylines, plush suburbs and a tourism service industry to rival that many western cities. Africans, who also travel quite significantly to global cities, are fast gaining a vast range of consumer options ranging from street and open

8 FDI is the investment from a company entity to another company in another country. Ownership of assets is retained by the parent company. One of the most important conclusions of modern growth theory in economics is that capital investment, through FDI is key to economic growth. No country has achieved sustained prosperity without significant participation from the FDI economy. 
markets, to supermarkets and specialty groceries, as well as online shopping platforms.(Bright; Hruby, 2015: 87; See also Youtube channel of Caroline Mutoko. She represents this newly reinvigorated world. Her February 2019 series of videos showcase what she calls the Retail Revolution. Mutoko, 2019) The rise of retail, and an African consumer class is related to the subject of the next segment-a change in demographics, particularly the maturing of a youth population into young adults who are driving and with the demographics, accompanying social indicators.

\section{The continent's demographic transformation to a young population}

The purpose of a stable political climate, and of steady economic growth is to improve the overall quality of life for all citizens. For a very long time, GDP was used as the primary measure of a country or region's progress. In 1990, the Human Development Index (HDI) was developed to highlight human capabilities, in addition to economic growth.("Human Development Index)," n.d.) HDI looks at three dimensions of well-being, namely, life expectancy at birth, educational attainment, and real GDP per capita. Demographers have come to talk of "social indicators" to track human development. These include educational attainment, gainful employment, rates of fertility, health conditions, opportunity for career growth and lifestyle improvement and level of income and wealth and inequality. Additional but subjective measures of quality of life include work-life balance, other life skills, social connections, civic engagement, living environment, personal security and spiritual and cultural embeddedness.

The most practical measures that help track Africa's improved social indicators over the last three decades are the Millennium Development Goals (MDGs). MDGs were an ambitious project by western nations, under the auspices of bilateral development agencies, with some publicity help from pop culture celebrities to reduce global poverty between 1990 and 2015. At the 2000 Millennium Assembly, global leaders committed to "spare no effort to free fellow humanity from the dehumanizing conditions of extreme poverty". This was translated into a framework of eight goals with wide-ranging practical steps and innovative partnerships. Targets included eradication of extreme poverty and hunger, universal primary education, gender equality, empowering women, improving maternal health and reducing child mortality, combating HIV/AIDs and safeguarding environmental sustainability. (Nations 2016) According the final UN report, MDGs were the most successful anti-poverty movement in history. They helped lift more than one billion 
people out of extreme poverty, drastically reduced hunger, sent more girls to school and rehabilitated the environment.

While aimed at the poor all around the world, MDGs had the remarkable impact of coalescing with earlier gains to trigger a demographic transition in Africa, with marked changes in the key social indicators of education, changing rates of fertility and improved health conditions. The most useful way to gauge these indicators is to see the change through the lens of the demographic transition model, a map of how populations are restructured as economic conditions of a country develop.(Lee, 2003; Teller; Hailemariam, 2011)rapid urbanization, dense rural populations and young age structures in the face of drought, poverty, food insecurity, environmental degradation, climate change, instability and the global economic crisis. However, while facile generalizations about the lack of demographic change and lack of progress in meeting the MDGs in sub-Saharan Africa are commonplace, they are often misleading and belie the socio-cultural change that is occurring among a vanguard of more educated youth. Even within Ethiopia, the second largest country at the Crossroads of Africa and the Middle East, different narratives emerge from analysis of longitudinal, micro-level analysis as to how demographic change and responses are occurring, some more rapidly than others. The book compares Ethiopia with other Africa countries, and demonstrates the uniqueness of an African-type demographic transition: a combination of poverty-related negative factors (unemployment, disease, food insecurity.

Figure 1: A demographic transition graph (Wikipedia, 2019)

\section{The demographic transition in 5 stages}

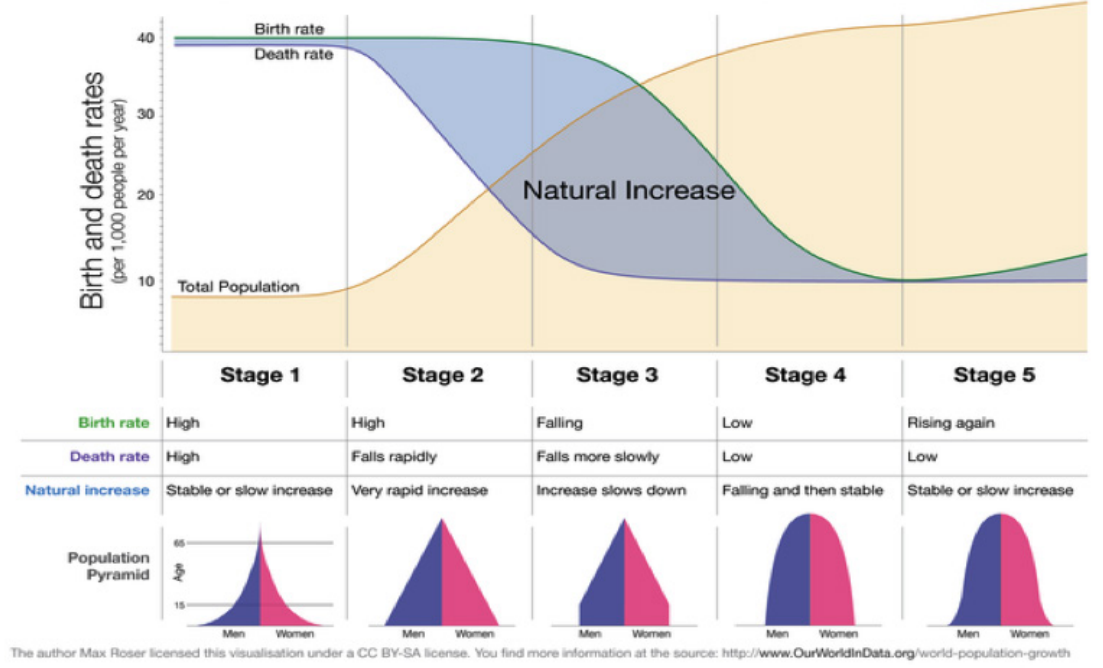


First, the combination of fertility and mortality determines the rate of population growth. Unstable populations are characterized by high birth and correspondingly high death rates. Stable populations begin to balance out with low birth and low death rates, with the middle segments of a population moving towards productivity. In the idealized demographic transition curve, countries move through several stages as they develop, with consequences on the birth and death rates of their populations, thus population size. The first stage is decline in death rates (decline in mortality rate) due to reductions in infectious diseases and access to better nutrition. The second step is fertility transition. When technological progress and better human capital make labor more productive, this step raises the value of time in all activities, which increases the cost of having children and therefore reduces the number of children being born. Children also go to school, ending their participation in family economic activities. Parents devote more resources per child, which means they bear fewer children. With more adults gainfully employed in productive economic activity and having fewer children, there is a shift to the demographic divided. The improved conditions also mean there is improved health, therefore fewer death rates and people live longer.

A demographic curve requires different types of resources at different age stages. (YiFu Lin, 2012) Young children and their mothers need health facilities. On reaching school age, children require educational resources. Older youth need institutions of tertiary education and facilities of life skills development, then jobs with adequate salaries, and as they mature and settle, infrastructure for housing and mobility. If these resources are available, they become economically productive to the country. If working age individuals can be fully employed in productive activities, fertility rates decline, and other things equal, the level of average per capita income in a nation should increase, and the youth bulge will become a demographic dividend, meaning an increase in the productive population-a middleclass. The correlated scenario is where child mortality rates decline, that is, fewer children die. They grow into young adulthood, but a country's economic conditions do not allow for gainful economic activity for adult population. Rather than a demographic divided, a demographic timebomb can be the result, in which a large unemployed young adult population could imply potential breeding ground for crime and antisocial activities, civil disaffection, war, or recruitment into terrorist activities. 
This detailed clarification of the demographic transition is significant to understanding Africa's current stage in its population structure, and the place of youth and young adult population. The overall impact of the millennium development goals in Africa is that since the 1990s, child mortality rates have declined drastically. While agency of African mothers and fathers is core to this transformation, the substantial turnaround in reducing senseless deaths on a continental scale required the global goodwill as galvanized by the MDGs together with NEPAD, the New Partnership for Africa's Development, the joint economic project of the African Union.(See Sachs 2005)"plainCitation":"(See Sachs 2005 The fight to combat diseases such as TB, HIV/AIDs, malaria as well as availability of healthcare facilities equipped with medicine for basic ailments in both rural and urban Africa enabled a lot of children to survive. The evidence of that success is in Africa's current population pyramid, seen in the figure 2 below. Africa's population, especially compared to that of China and Brazil is large at the base, meaning Africa has just began the demographic transition curve. The other nations are further ahead in terms of their transition towards a demographic dividend.

In the aggregate, lower mortality rates and better nutrition means that most African children born in the 1980s and 1990s have come to young adulthood beginning the 2000s. Fertility rates remained high for the next decade, therefore more children were born up until the 2000s. UN Data records that the median African age is about 19.9 years, compared to the global median age of 29.9 years. Children under the age of 15 account for $41 \%$ of Africa's population in 2015, and young persons aged 15-24 account for a further $19 \%$, meaning that $68 \%$ of the entire African population that is under the age of 24. (United Nations 2015; Sivi 2010) 
Figure 2: The population pyramids of Africa, China and Brazil, 2015, 2016. Source: Disponível em: <https://www.populationpyramid.net>. Acesso em: 18 set. 2019. (“Population Pyramids of the World 2015 and 2016" 2016)

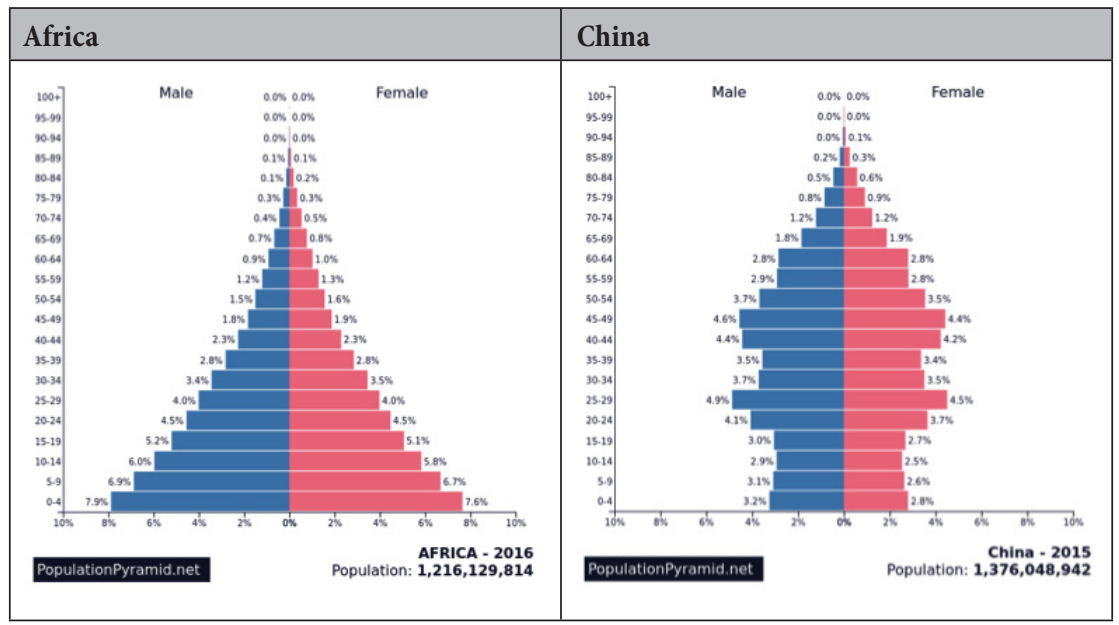

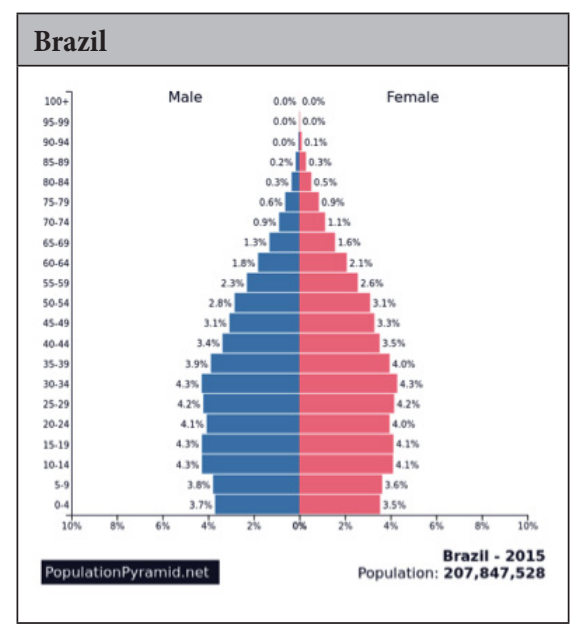

To follow further on the implications of the transition, below is a table with various datasets for 10 countries that have the highest populations in Africa: Nigeria, Egypt, Ethiopia, Democratic Republic of Congo, South Africa, Kenya, Tanzania and Uganda. 
政

产

害

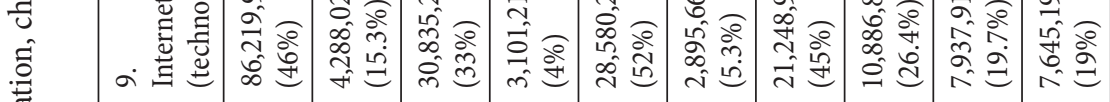

苞

눌

言窟妾

บับ

言

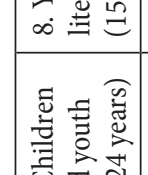

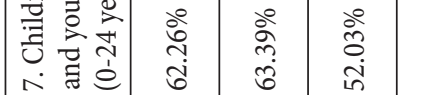

\begin{tabular}{|c|c|c|c|c|c|c|c|c|c|}
\hline 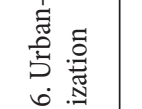 & $\begin{array}{l}\circ \\
0 \\
0 \\
0\end{array}$ & $\begin{array}{l}\text { هo } \\
\text { aे }\end{array}$ & لs. & 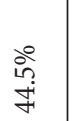 & & & ${ }^{4}$ & 总 & 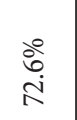 \\
\hline
\end{tabular}

喜

:

咅

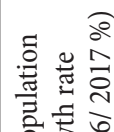

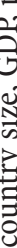

音

言

言咅

章

言

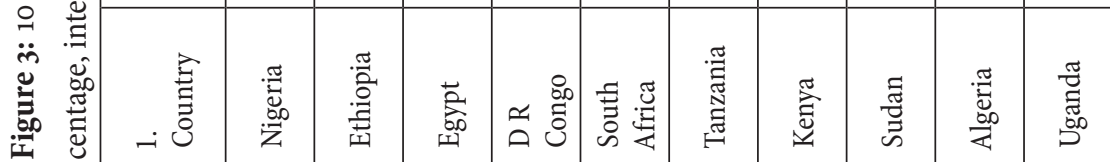


This table is intended to make several points. As pointed out earlier, the transition of the African population curve is ascribed to the MDGs. A perception persists, that African birthrates continue to rise exponentially. However, this perception is not correct. While the current high percentages of children and youth, as in column 7 in the table, does in fact mean significantly higher population growth rates are to be expected in the next several decades, 20162017 data from CIA Factbook shows that African women fertility rates have been dropping significantly in all but a few countries. Column 4 in the table shows those percentages for ten of the countries with the highest populations. The highest of these is Uganda, with a rate of $3.18 \%$ which is not alarmingly high, and several of the other countries have dropped beyond replacement ratio.

The other correlated and successful goal of the MDGS was to increase the number of children who make it into primary and secondary school, particularly the concerted effort to increase the number of girls in school and therefore reduce the number of young mothers, therefore reduce the number of children per woman. Column 7 shows the number of children and youth, which as just said, are more than half of the population in all countries except South Africa and Algeria. This is explained by the fact that the demographic transition just began, with a lot of children being saved from early death in the 1990s. But correspondingly, column 8 shows a relatively high youth literacy rate, and is continuing to rise each year. Birth rates will continue to decline, and less children will be born in coming decades.

Besides the fact that the rates of population growth are dropping quite rapidly, Africa's geographical size is not even closely correlated with that of other regions. Compared to Africa's population of only 1.2 billion, India and China, whose geographical landmasses are smaller, these regions are far more populated with more than a billion people each. Besides, the world population stands at 7.6 billion because all the other continents experienced exponential population growth in early to middle decades of the twentieth century. That population boom, which excluded Africa at the time led to the publication of a popular book, The Population Bomb by Stanford Biologist Paul Ehrlich.(Ehrlich, 1973) Ehrlich inaccurately predicted mass starvation and social upheavals in the 1970 and 1980 os due to overpopulation. Ehrlich's predictions did not come true because the world learnt how to feed itself through what became known as the Green Revolution. ${ }^{10}$ (Jain 2010)"publisher":"The Green Revolution:

10 The term green revolution was coined to refer to the record yields of wheat in Pakistan, India and Turkey and rice in the Philippines, made possible with the adoption of a new agricultural technology in the form of high-yielding seed varieties, plant breeding, use of fertilizers, irrigation and pesticides. In subsequent years, improved methods have ensured the production of sufficient food, including in Africa, even as population has continued to grow. 
Histor'"'number-of-pages":" 4,'”source":"Google Books"',ISBN":"'978-1-93369963-9'"'note":"Google-Books-ID: oaC62aMi_ToC','shortTitle":"Green Revolutio

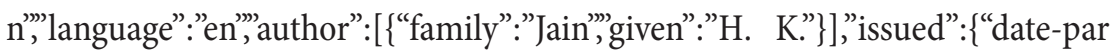
ts":[[“2010"]]\}\},"suffix":"The term green revolution was coined to refer to the record yields of wheat in Pakistan, India and Turkey and rice in the Philippines, made possible with the adoption of a new agricultural technology in the form of high-yielding seed varieties, plant breeding, use of fertilizers, irrigation and pesticides. In subsequent years, improved methods have ensured the production of sufficient food, including in Africa, even as population has continued to grow."']],"schema":"https://github.com/citation-style-language/schema/raw/ master/csl-citation.json"\}.

Figure 4: The True Size of Africa (McCandless 2010)

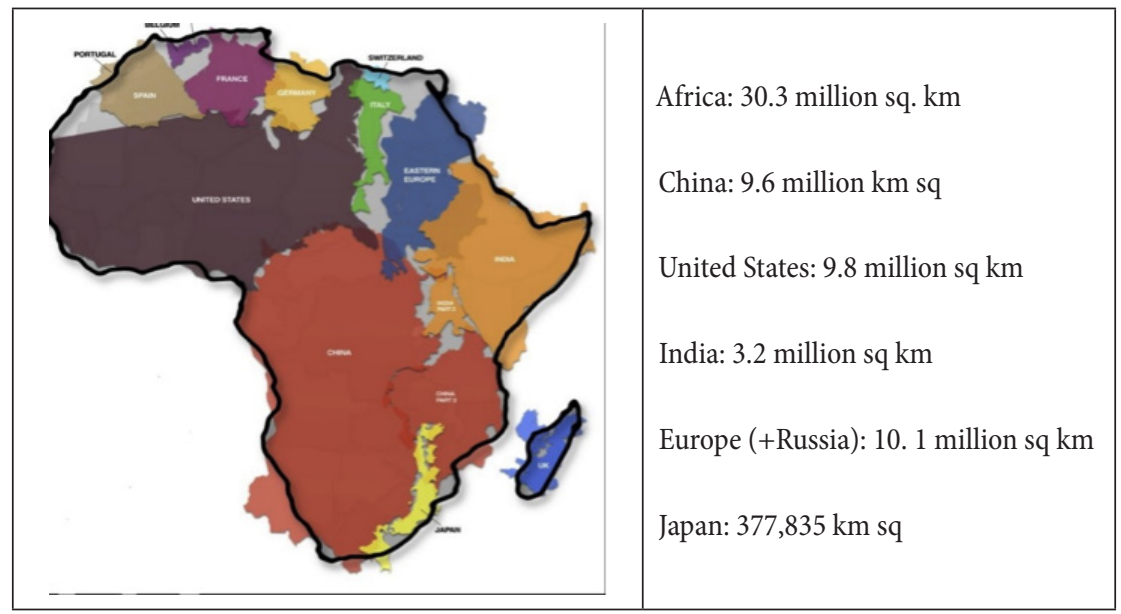

Column 2 in the table is intended to show that while most African countries have a growing youth and young adult populations as a result of the successes discussed above, the physical territories of most African countries are massive. A country like the D R Congo, which is six times the size of California, and which is highly endowed with numerous natural resources, even with 77 million inhabitants is actually underpopulated for its geographical size. Tanzania, Southern Sudan, Angola, Central Africa Republic and Mozambique are some of the other countries whose populations are far less, relative to their geographic size and natural resource endowments. Certainly, all these countries have other substantial challenges, but spurious correlations bundling up all the problems with population growth amounts to intellectual dishonesty. Getting the cause 
and effect factors right is critical, especially for countries that are just recently stabilizing out of war, and which, without a significant population base, will not be able to develop sufficient labor force and reliable productivity to grow into a middleclass and turn towards a demographic transition. To continue to claim that Africa is overpopulated on the basis of the big numbers of just one or two countries is equivalent to earlier imperialist and colonialist condescension that Africans have had to endure for centuries.

Today's growing alarmist prognoses concerning Africa’s population growth, whose demographic transition is catching up with patterns of other regions in earlier decades, not only echoes Erhlich's flawed fears from the 1970s, the alarms are also flat out wrong because they fail to consider other factors as far as Africa goes. First, on a negative note, current analyses are missing the rise of deadly cancer, which is compounding the deaths caused by malaria and TB that are still prevalent. A variety of cancers that are not correlated with HIV/ AIDs are now the third leading cause of death across Africa. Unlike other diseases, the burden of cancer is striking people at the prime of their productivity in their 30 and 40 , let alone those who are older and might get the disease because of age-related factors.(Nganga et al., 2017) Apart from flat generalities about cancer as a lifestyle disease, little research has been done on the epidemic because it is not a disease associated with dependencies that usually attracts donor funds. Unless swift intervention occurs, cancer will skew Africa's demographic transition for the worse.

On to more positive considerations, in earlier decades, the increase in populations in other regions of the world was correlated with the expansion of their economies. Formal education is the equalizing factor. Throughout the decade of 2000, nearly all African countries experienced marked advance not only in primary and secondary enrollments, there was also significant entrepreneurial growth in the technical, tertiary and university education sectors. The presence of a robust higher education sector is often overlooked in most analyses about education in Africa because it is more expedient to highlight what is missing. Yet higher education is not only a major contributor to economic growth, it is also behind the rise of a self-conscious globalizing, technologically and culturally savvy young adult generation. A lot of Africans travel to study in universities in other countries within the region. Kenya, South Africa and Ghana are some of the coveted destinations for private universities. Column 10 in the table above shows the numbers of public universities in those ten countries. These figures which do not include the equally high number of private universities and other tertiary institutions (further research needs to be done on Africa's higher education private sector) 
go to show what demographers who only highlight primary education overlook: many Africans are acquiring university education. A college-educated population is not only a resource for productivity and innovation both locally and abroad, it also grows into a consumer middle-class that also serves as a stabilizing influence on the political structures. ${ }^{11}$ (See Brandi; Buge, 2014)

The increase in number of children that acquired primary and high school education also means that this generation came into young adulthoods at a very important juncture: global expansion in information technology. While the mobile phone was invented in 1973, the first consumer friendly phones were released in the late 1990s. Similarly, computer and internet driven information technology came to the mass market in the late 1990s, not just in the world but also all over the world. Because China swiftly produced and marketed affordable laptops and mobile phone handsets to Africans, the revolution in information technology reached the African consumer market at the same time it reached the west, beginning the late 1990 os and expanding swiftly in the first half 2000s. This means that in terms of access to basic technologies of communication, information, knowledge, and cultural products, African millennials have largely been at par with western and Asian millennials.

Some of the prognoses of Africa's impending population explosion are treating Africans as perpetual dependents. This is erroneous. The yet to be developed segments of the continent currently represent a mass "market at the bottom of the pyramid", as case studies in Prahalad's The fortune at the bottom of the pyramid detail.12(Prahalad, 2006) The fast growing cities and urban centers also provide opportunities for booming construction industry, a factor well recognized not only by the Chinese who are docking in Africa's ports,(French 2014)Howard French is uniquely positioned to tell the story of China in Africa. Through meticulous on-the-ground reporting-conducted in Mandarin, French, and Portuguese, among other languages-French crafts a layered investigation of astonishing

11 In the immediate post-war decades, the west went through a similar period of growth as the same that Africa has been going through these last few decades. With expanded education opportunities, the emergence of a middleclass in the west was closely related to the large numbers of young people who graduated out of universities to become lawyers, doctors, lecturers, managers and administrative experts in the growing economies of the post-war west, as well as entrepreneurs, and a supportive blue-collar class that nonetheless had a stable employ. Although circumstances of automation is changing job dynamics, it is foreseeable that growth in higher education will similarly transform Africa.

12 For declining productivity of developed economies, solving the lingering problems among the poor is the key to creating new and fast-growing markets. The poor are not a liability. Providing goods and services to the poorest people in the world creates opportunities for innovation, entrepreneurship and combines fighting poverty and profitability. 
depth and breadth as he engages not only with policy-shaping moguls and diplomats, but also with the ordinary men and women navigating the street-level realities of cooperation, prejudice, corruption, and opportunity forged by this seismic geopolitical development. With incisiveness and empathy, French reveals the human face of China's economic, political, and human presence across the African continent-and in doing so reveals what is at stake for everyone involved. We meet a broad spectrum of China's dogged emigrant population, from those singlehandedly reshaping African infrastructure, commerce, and even environment (a self-made tycoon who harnessed Zambia's now-booming copper trade; a timber entrepreneur determined to harvest the entirety of Liberia's old-growth redwoods but also by African investors like Aliko Dangote, said to have a net worth of US\$10 billion. The Dangote Group has interests in oil, banking, construction, agriculture, technology and manufacturing, all structured to harness the needs of Africa's young population as an emergent market.(Forbes, 2019; Ogbor, 2009: 275) The rapid rate of urbanization is another significant feature. Column 6 shows the percentages of urbanization. With Africa moving from rural, subsistence agriculture-based economies, and populations resettling into towns and cities, the low rates of urbanization in countries like Uganda, DRC, Sudan, Kenya, Tanzania represent massive opportunities of economic growth.

Besides being absorbed in technology driven opportunities generated in the legacy sectors of urban growth, education and health, African young adults are taking a lead in reshaping the continent in a variety of other ways. Column 9 in the table above shows the percentage of internet use. Mobile phone use is far higher than internet use, yet the percentages of internet user are significantly high. One of the continent's most popular mobile phone services is M-Pesa. Launched in 2007 in Kenya by Safaricom, the service started out a simple medium of sending payments among people considered "unbankable", those with insufficient funds to open bank accounts, particularly women. In Kenya alone, M-Pesa now records upwards of US\$12 billion in annual transactions and has spawned imitations across Africa and around the world. The service has created thousands of jobs for low income earners and facilitated growth in middle-range industries and services. It also facilitates savings schemes that wholly bypass the credit card, and international remittances that drastically reduce operating costs. ${ }^{13}$ ("Safaricom," 2019.) Another electronic financial services platform is Interswitch, founded by Nigerian engineer Mitchell Elegbe. The service allows

13 M-pesa is the most easily told story of business success in Kenya, written about by every news outlet. More details can be found through M-pesa parent company, Safaricom. 
customers to transact online and process payments between financial providers without increasing costs while minimizing security risks. In the Nigerian context it also came as a bank to the unbanked.("Interswitch - Electronic Payment and Digital Commerce Solutions." 2019).

If education is one equalizer, affordable technology is the other because information is easily accessed, and a lot of technology-based skills are self-taught. Relatively inexpensive personal laptops, mobile phones and internet cybercafes have created a budding ecosystem of ideas around innovations, competitions, and regular service delivery across technology platforms. Quartz Africa reported that in 2017 and 2018 alone, about 130 tech hubs were opened around the continent, supported by venture capitalists, government-led youth initiatives and national telecommunication companies looking to harness the youth market.(Dahir, 2018).

The intersection of a college educated demographic with technology at a time when other economic arrangements have no secure jobs is that youth are compelled to tap into the short-term labor market, baptized as the gig economy in the west. The short-term labor market is not new to Africa; it has always existed as casual labor, that is, day jobs in farming, building, factories, popular entertainment, and women's initiatives in food, cultural artifacts, dress-making, household labor and beauty. Technology has just created better connectivity, which has increased chances to market skills to new constituents and negotiate fairer pay. Youth also offer emergent technology services to older enterprises such as hotels, travel, and tourism, media houses and newspapers. By curating fresh ideas from the internet to suit local cultures, they are also revitalizing entertainment through comedy, music, movies and video. Connections that can be traced on business networking sites like LinkedIn are also indicative of how young people are building new professional relations, and publicizing their knowledge in business coaching, life-skill specialties, design and photography, culinary arts among others. These short-term opportunities are building new forms of social capital for a rapidly changing urban and global world. They are equally helping to navigate global networks; thus they are a cradle space for nurturing of critical versatility to cope with global socioeconomic disruption. Therefore, unlike earlier generations that were overwhelmed by intrusive global forces, this and future generations of Africans will not be blindsided by forces and events from other regions of the world. They are taking their place in the world and will in fact play an important role in shaping it future.

Some of the emergent ideas are revitalizing older arenas of economic activity. One is iROKO, founded by Nigerian Jason Njoku in 2011, a movie and music 
subscription service which rides on Nigeria's highly successful Nollywood movie industry. It has helped actors and musicians make their trade profitable. In turn, Nollywood creates a wide variety of movies that are relevant to Africa's village, urban and global demographics. Ghana has tech startup known as MEST, which has opened opportunities to train and link up with investment funds from global entrepreneurs. RLabs, founded in Cape Town, South Africa specializing in customized technology solutions for more more than 100,000 young people from marginalized communities. Numerous other startups are growing because they are connecting communities to essential services like access to needs of health, farming, retailing, online education and civic obligations. There is also different breed of youth focused initiatives, originating from a variety of religious communities. With majority of the population in sub-Saharan Africa being Christians, a lot of churches have initiatives rehabilitating, educating and life-skilling children and youth from disadvantaged backgrounds, or those drop out of school.(Priest; Kirimi, 2017). Not to mention that churches play a critical role in inspiring youth to aspire to a better life.

Some young Africans have made news with ingenious ideas that are yet to turn into creative enterprises but indicate the extent of talent across the region. (Beaurain, 2017). WoeLabs in Togo made the first "made in Africa" ${ }_{3} \mathrm{D}$ printer from e-waste. Buni Hub in Tanzania built 3D printers. Ugandan Brian Turyabagy created a biomedical smart jacket that accurately diagnoses pneumonia four times faster than a doctor and sends the information via Bluetooth to a smartphone. Richard Turere of Kenya created a set of lion lights that reduce human-wildlife conflict. Nigerian Kehinde Durojaiye has crudely assembled a floating car-plane out of scrap material, trying to solve his city's traffic gridlocks. South Africa is building the Square Kilometer Array space telescope, which, when completed will be the world's largest telescope-and is driving innovation in data analytics, storage and transport. An adapted form of space technology in Nigeria is collecting climate data to improve agricultural practices. South Africa has created the first Virtual Reality mine, allowing students to train in a simulated mining environment and the all too common avoid mining accidents.

Another arena of change is cultural and sociopolitical activism. While governments often need external pressure to bring structural change, social media, multiple radio and TV channels, and live streaming is enabling youth to expose corruption, challenge police brutality, and shame non-performing public sectors such as power companies, hospitals and road contractors. A younger class of African intellectuals are raising a chorus of dissent with their poorly performing governments, and social activists have become vocal and visible beyond 
country boundaries. Boniface Mwangi founder of Pawa254 in Kenya and Ugandan Bobi Wine (Robert Kyagulanyi) both have raised huge followings of youth for their fight against political dysfunction. Mwangi is an award-winning photojournalist for photographic exhibitions that challenged Africans to develop a civic consciousness. (Mwangi, 2016)"publisher":"Boom Twaff'”'publisher-place":"Nairobi',"'number-of-pages":"340','source":"Amazon"'”event-place":"Nai robi','abstract":" In just over a decade, Boniface Mwangi has risen from poverty to prominence in Kenya. He is renowned for his powerful photographs and his courageous protests calling for social justice. However, little is known about the man himself. UnBounded is a collection of engaging personal stories that takes us through some of the people, places and events that have shaped Boniface, easily one of Kenya best known photographers and activists. It is a portrait of the child, the man and some of the human, harrowing and even humorous episodes that he has witnessed and photographed. This book tells of the two remarkable women - his mother and grandmother - who influenced his character and inspired his drive to raise awareness about poverty, inequality and corruption. His work as a photo-activist is grounded in social engagement, collective action and the need for justice. This is the story of a man of determination and warmth, a man who lives his life to make a difference. We cannot change the world as individuals. We can only change the world together."' ISBN":"9789966-095-03-9'"'language":"English'”',author": [\{“family":"Mwangi','given":"Bon iface"\}],"issued”:\{“date-parts":[[“2016",10,1]]\}\}\}],"schema”:"https://github.com/ citation-style-language/schema/raw/master/csl-citation.json"\} . Kenyan public intellectual Wandia Njoya and a team of other well-educated Africans challenge systematic state abuses through concise writing on their social media platforms. (Njoya, 2019). Blogs award platforms such as South African Blog Awards, Kenya's BAKE Awards, Jamii forums in Tanzania, Uganda blogging community, among others are increasingly acting as platforms for social, cultural and civic awakening. Another is set Youtubers and vloggers, showcasing emergent talent, skill and artistry. Others are producing art using paintings, drawings, stencil, outdoor murals, garish symbolism, videos and photography to address economic sabotage by the corrupt political class. Kudzani Chiurai of Zimbabwe became internationally recognized for producing art challenging Mugambe's brutal grip on power. ("Kudzanai Chiurai - 125 Artworks, Bio \& Shows on Artsy," 2019.) In Kenya, graffiti artists painted murals in the city center depicting corrupt leaders as vultures preying on the most vulnerable. They also desecrated parliament grounds with grotesque effigies and the blood of pigs to caricature MPs for awarding themselves hefty salaries. Even in countries where political 
repression still limits activism, youth are still at the forefront of rebuilding their nations. For example, in Central African Republic, a country of 4.6 million people recently torn apart by civil war, youth are organizing through religious communities such as the Catholic Scouts Association to get other youth to return to school, get vaccinated, and deescalate conflict.

These are highlights of the energies unleashed by a young population that is maturing at the intersection formal education, expanding technology, and the absence of a solid job market. This demographic faces a major unrealistic expectation, that they will deliver the so-called magic bullet of youth entrepreneurship. Youth will certainly hustle to create opportunities where there are none, but given all the vibrancy and excitement they generate, there a risk that governments and global bilateral organizations will slack in providing critical infrastructure. Startup initiatives are inadequate for keeping economies revitalized. Governments need to create and implement the right policies to strengthen all levels. They also need provide the medical, housing and technical infrastructure that will facilitate a demographic transition from the youth bulge towards a middle class.

\section{Conclusion}

This paper has covered extensive ground, seeking to articulate a fuller narrative of Africa rising. This paper is not in itself adequate to articulate all the ways the continent is changing, especially granted the geographic, linguistic and sociopolitical differences. Yet this paper goes to show that continuing conversations among agents in the media, in academia, among demographers, bilateral organizations and governments need to be detailed, nuanced and multifaceted. Better understanding and interpretation of data, proper representation of the continent's achievements, opportunities and challenges is critical to forging the desired future.

\section{References}

AFRICA'S impressive growth - daily chart. The Economist, January 6, 2011. Disponivel em: $<$ https://www.economist.com/graphic-detail/2011/o1/o6/africas-impressive-growth>. Acesso em: 30 jan. 2019.

DANGOTE, Aliko. CEO, Dangote Group. Forbes. Disponível em: <https://www.forbes. com/profile/aliko-dangote/\#7cb145ee22fc>. Acesso em: 17 set. 2019

BEAURAIN, François; YEMISI, Adegoke. The Nigerian inventor who wants to build a flying jet car. CNN, 2017. Disponível em: <https:/www.cnn.com/2017/04/o7/africa/ jet-car-nigerian-inventor-flying/index.html>. Acesso em: 17 set. 2019. 
BONGMBA, Elias. The Dialectics of Transformation in Africa. New York, Palgrave Macmillan US, 2006.

BRANDI, Clara; BUGE, Max. A Cartography of the New Middle Classes in Developing and Emerging Countries. Tulpenfed, Deutsches Institut Für Entwicklungspolitik, 2014.

BRIGHT, Jake; HRUBY, Aubrey. The Next Africa: An Emerging Continent Becomes a Global Powerhouse. New York, Macmillan, 2015 (304).

MUTOKO, Caroline. Caroline Mutoko Youtube Channel: My Spotlight. Disponível em: $<$ https://www.youtube.com/channel/UCXhzyOoaIZtrBdHqyn3VMxg >. Acesso em: 17 set. 2019.

CENTRAL Intelligence Agency. The World Factbook 2016-2017. Disponível em: <https:// www.cia.gov/library/publications/the-world-factbook/>. Acesso em: 17 set. 2019

CHARLES, Teller; ASSEFA, Hailemariam. The Demographic Transition and Development in Africa: The Unique Case of Ethiopia. Springer Science \& Business Media, 2011.

CHIURAI, Kudzanai. 125 Artworks, Bio \& Shows on Artsy," 2019. Disponível em: $<$ https://www.artsy.net/artist/kudzanai-chiurai $>$. Acesso em: 16 set. 2019.

COLLIER, Paul. The Bottom Billion: Why the Poorest Countries Are Failing and What Can Be Done about It. New York, Oxford University Press, 2007 (272).

DAHIR, Abdi Latif. Africa's Newest Startup Hubs Are Expanding beyond Its Legacy Tech Markets, Quartz Africa, 2019. Disponível em: <https://qz.com/africa/1234168/ africas-newest-tech-hubs-are-in-senegal-ghana-cote-divoire-zimbabwe-uganda/> . Acesso em: 16 set. 2019.

DEMOGRAPHIC Transition. Wikipedia. Disponível em: <https://en.wikipedia.org/w/ index.php?title=Demographic_transition\&oldid=88675563. Acesso em:

EDKINS, Adrienne. Cancer: Not an African Problem? Science in Africa, S.d. Disponível em: <http://www.scienceinafrica.com/biotechnology/health/cancer-not-africanproblem>. Acesso em: 16 set. 2019.

EHRLICH, Paul R. The Population Bomb. New York, Sierra Club/Ballantine, 1973 (201). FRENCH, Howard W. China's Second Continent: How a Million Migrants Are Building a New Empire in Africa. New York, Knopf, 2014 (285).Howard French is uniquely positioned to tell the story of China in Africa. Through meticulous on-the-ground reporting-conducted in Mandarin, French, and Portuguese, among other languages-French crafts a layered investigation of astonishing depth and breadth as he engages not only with policy-shaping moguls and diplomats, but also with the ordinary men and women navigating the street-level realities of cooperation, prejudice, corruption, and opportunity forged by this seismic geopolitical development. With incisiveness and empathy, French reveals the human face of China's economic, political, and human presence across the African continent-and in doing so reveals what is at stake for everyone involved. We meet a broad spectrum of China's dogged emigrant population, from those 
singlehandedly reshaping African infrastructure, commerce, and even environment (a self-made tycoon who harnessed Zambia’s now-booming copper trade; a timber entrepreneur determined to harvest the entirety of Liberia's old-growth redwoods

GIFFORD, Paul, African Christianity: Its Public Role. London, Hurst, 1998 (368).

HAMRELL, Sven; NORDBERG, Olle. Towards a Second Liberation: Africa and the World Crisis. Development Dialogue: A Journal of International Development Cooperation, v. 2, 1987.

HANCILES, Jehu. Beyond Christendom: Globalization, African Migration and the Transformation of the West. Maryknoll, NY, Orbis Books, 2009 (430).

INTERNATIONAL MONETARY FUND. Regional Economic Outlook: Sub-Saharan Africa. World Economic and Financial Surveys, 0258-7440. Washington, DC, International Monetary Fund Report, 2009.

INTERNET World Stats: Usage and Population Statistics. Africa Stats. Disponível em: <https://www.internetworldstats.com/stats1.htm>. Accesso em: 16 set. 2019.

JAIN, Hari Krishan. Green Revolution: History, Impact and Future. Houston, Studium Press LLC, 2010.2010

JERVEN, Morten. Poor Numbers: How We Are Misled by African Development Statistics and What to Do about It. New York, Cornell University Press, 2013 (208).

KATONGOLE, Emmanuel. The Sacrifice of Africa: A Political Theology for Africa. Grand Rapids, Eerdmans, 2011 (203).

KEIM, Curtis A. Mistaking Africa: Curiosities and Inventions of the American Mind. Philadelphia. Avalon Publishing, 2013 (256).

RONALD, Lee. The Demographic Transition: Three Centuries of Fundamental Change. The Journal of Economic Perspectives, v. 17, n. 4, 2003.

LINDBERG, Staffan I. The Surprising Significance of African Elections. Journal of Democracy v. 17, n. 1, February 1, 2006, pp. 139-151.

MAATHAI, Wangari. The Challenge for Africa. New York, Pantheon Books, 2009 (336). MAZRUI, Ali A. The African Condition: A Political Diagnosis. Cambridge, MS, Cambridge University Press, 1980 (142).

MCCANDLESS, David. The True Size of Africa," 2010. Disponível em: <http://www. informationisbeautiful.net/2010/the-true-size-of-africa/>. Acesso em: 17 set. 2019.

MEREDITH, Martin. The State of Africa: A History of Fifty Years of Independence. New York, London, Free Press, 2006 (608).

MOYO, Dambisa; FERGUSON, Niall. Dead Aid: Why Aid Is Not Working and How There Is a Better Way for Africa. New York, Farrar, Straus and Giroux, 2010 (208). MWANGI, Boniface. Boniface Mwangi Unbounded. Nairobi, Boom Twaff, 2016 (340).

NEWMAN, Carol. Made in Africa: Learning to Compete in Industry. Washington, DC, Brookings Institution Press, 2016. 
NG'ANG'A Ann. Africa's Emerging Cancer Crisis: A Call to Action. Nairobi: African Organization for Research and Training in Cancer and Bio-ventures for Global Health. 2017.

NJOYA, Wandia. Disponível em: <https://www.wandianjoya.com/about.html>. Acesso em:

OGBOR, John. Entrepreneurship in Sub-Saharan Africa: A Strategic Management Perspective. Lagos, AuthorHouse, 2009.

POPULATION Pyramids of the World 2015 and 2016. Disponível em: <https://www. populationpyramid.net>. Acesso em: 17 set. 2019.

PRAHALAD, C. K. The Fortune at the Bottom of the Pyramid. Pearson Prentice Hall, 2006 (432).

ROXBURGH, Charles. Lions on the Move: The Progress and Potential of African Economies. McKinsey. 2010, https://www.mckinsey.com/featured-insights/ middle-east-and-africa/lions-on-the-move. Acesso em: 17 set. 2019.

RUSSELL, Alec. Big Men, Little People: The Leaders Who Defined Africa. New York, NYU Press, 1999 (256).

SACHS, Jeffrey. The End of Poverty: Economic Possibilities for Our Time. New York, Penguin Press, 2005 (448).\{\li\{\}The End of Poverty: Economic Possibilities for Our Time\} (New York|lucollu8239\{\}: Penguin Press, 2005., 2005

SAFARICOM. Disponível em: <https://www.safaricom.co.ke/about/about-safaricom/ who-we-are/our-story>. Acesso em: 17 set. 2019.

SIMMONS, Ann M. African immigrants are more educated than most - including people born in the US. Disponível em: <http://www.pewglobal.org/2018/04/24/ sub-saharan-african-immigrants-in-the-u-s-are-often-more-educated-than-those-in-top-european-destinations/>. Acesso em: 17 set. 2019.

SIVI, Katindi. Youth fact book: infinite possibility or definite disaster? Nairobi, Kenya, Institute of Economic Affairs and Friedrich-Ebert-Stiftung. 2010.

TEMPLE, Jonathan. Initial conditions: social capital and growth in Africa. Journal of African Economies, v. 7, n. 3, 1998, pp. 309-47.

UNITED NATIONS DEVELOPMENT PROGRAM. Human development reports: Human development index. Disponível em: <http://hdr.undp.org/en/content/ human-development-index-hdi>. Acesso em: 17 set. 2019.

UNITED NATIONS. United Nations millennium development goals report, 2015. Disponível em: <http://www.un.org/millenniumgoals/news.shtml>. Acesso em: 17 set. 2019.

UNITED NATIONS. World population prospects: key findings. Department of Economic and Social Affairs, Population Division, 2015. Working Paper, No. ESA/P/ WP.241, 2015. 
WORLD BANK. Migration and remittances factbook 2016, third edition. World Bank, 2016. Disponível em: <http://www.worldbank.org/en/research/brief/migrationand-remittances $>$. Acesso em:

WORLD DATA ATLAS: World and regional statistics, national data, maps, rankings. Disponível em: <https://knoema.com/atlas >. Acesso em: 17 set. 2019

YIFU LIN. Youth bulge: A demographic dividend or a demographic bomb in developing countries? Let's talk development. 2012. Disponível em: <http://blogs.worldbank. org/developmenttalk/youth-bulge-a-demographic-dividend-or-a-demographicbomb-in-developing-countries $>$. Acesso em: 17 set. 2019.

YOUTH Policy Labs: African internet users. Disponível em: <http://www.youthpolicy. org/library/>. Acesso em: 17 set. 2019.

Recebido em: 23/04/2019

Aprovado em: 25/11/2019

\section{Como citar este artigo:}

GITAU, Wanjiru M. The Transformation of a Young Continent: Dimensions of Africa Rising. Contemporânea - Revista de Sociologia da UFSCar, v. 9, n. 2, maio - agosto 2019, pp. 401-429. 